\title{
FRAMEWORK FOR ASSESSING TECHNOLOGICAL INNOVATION CAPABILITY IN RESEARCH AND TECHNOLOGY ORGANIZATIONS
}

\section{Sara Sadat MORTAZAVI RAVARI ${ }^{1}$, Ehsan MEHRABANFAR ${ }^{2}$, Audrius BANAITIS ${ }^{3}$, Nerija BANAITIENE $\dot{E}^{4}$}

\author{
${ }^{1}$ Strategy Planning department, RIPI, Tehran, Iran \\ ${ }^{2}$ Islamic Azad University, Young Researchers and Elites club, North Tehran Branch, Tehran, Iran \\ 3, 4 Department of Construction Economics and Property Management, \\ Vilnius Gediminas Technical University, Sauletekio al. 11, LT-10223 Vilnius, Lithuania \\ E-mails: ${ }^{1}$ mortazavis2@ripi.ir; ${ }^{2}$ e.mehrabanfar@aut.ac.ir; \\ 3audrius.banaitis@vgtu.lt (correspondingauthor); ${ }^{4}$ nerija.banaitiene@vgtu.lt
}

Received 11 November 2015; accepted 24 October 2016

\begin{abstract}
This study aims to evaluate technology innovation capabilities (TICs) of research and technology organizations (RTOs) by applying Fuzzy-DEMATEL \& ANP techniques, in order to provide a practical lookout for their firm's requirement in this regard. Based on literature review, six main criteria and eighteen sub-criteria are extracted. FuzzyDEMATEL is applied to analyze the casual relationships among the criteria and subcriteria. After identifying the relations between the criteria a questionnaire is developed and distributed among sixteen experts to assess the validity of the questionnaire, then the relations are weighted by ANP. It is concluded that proposed model is a comprehensive model that integrates qualitative and quantitative approaches to develop a step by step model to reach to the main TICs criteria in RTOs. Although, there are many previous researches illustrating various models to evaluate TICs, there is no formidable one using these techniques combination. Based on the abilities of the techniques and the results emerged this paper has prepared a robust model available for other RTOs to adopt as a true reference to reach to their TICs.
\end{abstract}

Keywords: technology innovation capability (TIC), research and technology organization (RTO), Fuzzy-DEMATEL model, ANP, research institute of petroleum industry (RIPI), innovation, technology.

JEL Classification: Q33, L24, C44.

\section{Introduction}

Technological innovation is an iterative process started by apprehension of a new market or a new service opportunity resulting in development, production, and marketing tasks in order to catch commercial success (OECD 1991). Innovation has been considered as the major factor for strengthening competitiveness of companies and gaining the 
new opportunity of the new market (Yang et al. 2015). Accordingly, innovation process includes technological development of an invention, merged with market introduction to end-users via adoption and diffusion; it also should occur iteratively meaning that after first introduction of the innovation, improved innovation should be reintroduced (Garcia, Calantone 2002). Technological innovations embody inventions from any field such as in engineering, applied sciences or pure sciences. At large scale technological innovations benefit the society by proliferating growth of the whole industry and at grass root level it influences individual enterprises and partners involved by their growth (Gupta, Barua 2016). In this regard, innovation is not necessarily related to problem solving, however it is usually related to improving competitiveness and economic success, and it is often pushed by technology (Galbraith 1996; OECD/Eurostat 2005). Based on OECD (1991), innovation could be any improved form of a product or process, such as a new method in business practices, workplace, organization or external relations. The most important aspect in regard with needs of organisations is to understand that how they can develop or assess their capability to build up technology innovation. In order to reach to this goal, Technological Innovation Capability or TIC is the target concept which should be studied. TIC is a special asset of an enterprise, which comprises different key areas, such as technology, production, process, knowledge, experiences and organization (Guan et al. 2006). TIC allows companies to adapt rapidly changing markets and customer's expectation in achieving innovation-driven growth. Improving TIC can enhance competitiveness of companies. TIC should be understood especially by those organizations involved in technology and research such as research and technology organizations (RTO); because they play a dominant role in supporting economic development and competitiveness (Shafia et al. 2016) and usually are the leaders of technology innovation in their industry.

This model is developed in RIPI, Research Institute of Petroleum Industry, one of the main oil companies in Iran petroleum industry aiming to create added value via production and commercialization of technology, with the approach of carrying out fundamental, applied, and developmental research for development and indigenization of new technologies. Both Fuzzy DEMATEL \& ANP methods are used to evaluate the results. The literature is deeply reviewed to find the main criteria and respective sub criteria of technological innovation capability; then they are classified based on each item referred scholar's. The final output of this step is provided in an expert panel comprising of 16 pro experts of the field; so then they have put the criteria and sub criteria under analysis which gave us a list of 6 main criteria and 18 attributed sub criteria. Then, fuzzy DEMATEL is applied to analyze the cause and effect relationships among the criteria and sub criteria; so the intensity among the relationships is appraised. After this step ANP test is applied to find out the weights of each criteria and the attributed sub criteria. Accordingly, this process has led to reach to a point of decision to state the main criteria influencing the TICs in RTOs.

This paper aims to introduce a step by step model to help RTOs identify their TICs by a systematic approach so that they can understand deeply the underlying causes of their technological innovation capabilities. This paper also seeks to answer to this question 
that what main factors are the determinative capabilities in RIPI by using the proposed model; and to find out that if the techniques used in the model are reliable enough to lead us to efficient results.

\section{Literature review}

\subsection{Technological innovation capability (TIC)}

As Panda and Ramanathan (1996) believe, technological capability is in fact a group of abilities, portrayed in the performance of a firm by different technological actions; and its final objective is to lead organization toward value management by developing organizational abilities. Burgelman et al. (2004) also proposed TIC as a comprehensive set of characteristics which facilitates technological innovation strategies of a firm. García-Muiña and Navas-López (2007) refer to the term strategic technological capability, which they conceptualize as an ability to develop a new product or process by employing competitive strategy and creating value. In this regard, TIC based on vast majority of scholars' definitions refers to the ability of providing major improvements to current technologies, which will lead to create new technologies. Lall (1992) defines TIC as a combination of skills and knowledge needed to effectively absorb, master and improve current technologies, and then to create new ones. Capaldo et al. (2003) evaluate the degree of TIC on the basis of the following subset of resources: entrepreneurial, human, resources linked to external networks and economic resources. Wonglimpiyarat (2010) provides five different dimensions in order to make an analysis of TIC which considers: organization, process, service, product, and marketing.

TIC is one of the most fundamental areas of study in the field of technological innovation management. TIC also is related to other fields in management such as strategic management, and it is known as one of the most important sources of competitive advantage (Coombs, Bierly 2006). Organizations with a high status of TIC, beyond their innate ability to provide innovative processes or products, have the ability to perform any relevant technical function or high volume activity (Teece et al. 1997). In other words, TIC is a special asset related to different key areas which one of them is technology, but there are a lot more such as production, process, knowledge, experiences and organization (Urueña et al. 2016; Camisón, Villar-López 2014; Yang et al. 2015; Boly et al. 2014; Hu 2012; Zhao et al. 2013; Gupta, Barua 2016).

Due to the importance of TIC, previous scholars had paid attention to explore the issues of improving TICs that can be beneficial to firm and lead to enhanced competitiveness. Accordingly, a research and technology firm should interact with TICs in order to enhance its capacity to innovate and achieve competitiveness.

\subsection{Technological innovation in RTOs}

Firms' utilization of sources of knowledge started a fast growth after the late 1980s (Hagedoorn 2002; Amara, Landry 2005), which increased in return the interest of academics and policy-makers. As knowledge can be a source of competitiveness, firms are increasingly turning to Research and Technology Organizations (RTOs) to search for the 
knowledge required to be competitive (Barge-Gil, Modrego 2011). However, RTOs have been faced with new challenges in recent years. They have to compete increasingly for research funds and also match with emerging research fields (Gibbons et al. 1994). In order to solve these issues these establishments have experienced reorganization to be able to serve the needs of industry more effectively (Arnold et al. 1998).

According to European Association of Research and Technology Organizations (EARTO), RTOs are generally a kind of non-profit organizations, which are generally classified as organizations providing $\mathrm{R} \& \mathrm{D}$, technology and innovation services to enterprises, governments (EARTO 2010).

The UK Association of Independent Research and Technology Organizations (AIRTO) believes since the outstanding objective of RTOs is to promote industrial competitiveness by technological means, they can only do their job if they in fact are technologically capable and can offer firms inputs that are in advance of or otherwise superior to those available on accessible commercial knowledge markets.

Most RTOs thus operate with an innovation model that involves:

- Exploratory research to develop a technology platform;

- Further work to exploit that knowledge in relatively unstandardized ways, often in collaborative projects with industry;

- More routinized exploitation of the knowledge, including via consulting, licensing, spin-off company formation.

EARTO (2010) expands the necessities for "the more routinized exploitation" of the above step:

- Availability of skilled human resources;

- Availability of seed-funding for the early stages of the process;

- Availability of suitable capital plant for carrying out the work;

- Funding over a sufficiently long period to enable later stages of the process to be tackled;

- Relationships with end-users who can exploit the innovation industrially.

\subsection{TIC measurement criteria}

Different studies have identified different criteria to measure TICs in firms. Table 1 summarizes different TIC measurements used in approaches proposed by different scholars:

Table 1. TIC measurement approaches

\begin{tabular}{|c|c|}
\hline Scholars & TIC measurement approaches \\
\hline Adler and & They provided four types of TICs: \\
\hline \multirow{4}{*}{$\begin{array}{l}\text { Shenbar } \\
(1990)\end{array}$} & 1. Capability of satisfying market requirement by developing new products; \\
\hline & $\begin{array}{l}\text { 2. Capability of manufacturing these products by using appropriate process } \\
\text { technology; }\end{array}$ \\
\hline & $\begin{array}{l}\text { 3. Capability of satisfying future needs by developing and introducing new products } \\
\text { and new process technology, and; }\end{array}$ \\
\hline & $\begin{array}{l}\text { 4. Capability to respond to an unanticipated technology activity brought about } \\
\text { by competitors and unforeseen circumstances. }\end{array}$ \\
\hline
\end{tabular}


End of Table 1

\begin{tabular}{|c|c|}
\hline Scholars & TIC measurement approaches \\
\hline $\begin{array}{l}\text { Christensen } \\
\text { (1995) }\end{array}$ & $\begin{array}{l}\text { He argued that while most firms typically focus on one of these four assets, } \\
\text { successful innovation requires combining multiple assets: } \\
\text { 1. Science research; } \\
\text { 2. Process innovation; } \\
\text { 3. Product innovation; } \\
\text { 4. Esthetics design. }\end{array}$ \\
\hline $\begin{array}{l}\text { Yam et al. } \\
(2004)\end{array}$ & $\begin{array}{l}\text { They applied statistical regression analysis to determine the main TICs at Chinese } \\
\text { firms in Beijing based on these seven capabilities: } \\
\text { 1. Learning; } \\
\text { 2. R\&D; } \\
\text { 3. Resource allocation; } \\
\text { 4. Manufacturing; } \\
\text { 5. Marketing; } \\
\text { 6. Organizing; } \\
\text { 7. Strategic planning. }\end{array}$ \\
\hline $\begin{array}{l}\text { Burgelman } \\
\text { et al. (2004) }\end{array}$ & $\begin{array}{l}\text { They proposed an innovative capability audit framework including five audit } \\
\text { dimensions: } \\
\text { 1. Resource availability and allocation; } \\
\text { 2. Capacity to understand competitor's innovative strategies \& industry evolution; } \\
\text { 3. Capacity to understand technological developments; } \\
\text { 4. Structural and cultural context; } \\
\text { 5. Strategic management capacity. }\end{array}$ \\
\hline $\begin{array}{l}\text { Wang et al. } \\
(2008)\end{array}$ & $\begin{array}{l}\text { They proposed a method for assessing the TICs of a firm and also obtain useful } \\
\text { information regarding hierarchical TICs frameworks. In this method they defined } \\
24 \text { criteria to fully explain the five main aspects: } \\
\text { 1. R\&D; } \\
\text { 2. Innovation decision; } \\
\text { 1. Marketing; } \\
\text { 2. Manufacturing; } \\
\text { 3. Capital. }\end{array}$ \\
\hline Heng (2011) & $\begin{array}{l}\text { He established a dynamic criteria system of large and medium-sized industrial } \\
\text { enterprise's TIC composed of six sub-criteria: } \\
\text { 1. Scientific \& technological innovation environment; } \\
\text { 2. Scientific \& technological investment; } \\
\text { 3. Scientific \& technological performance; } \\
\text { 4. Systematic principle; } \\
\text { 5. Comparable principle; } \\
\text { 6. Operational principle and the dynamic principle of continuity. }\end{array}$ \\
\hline $\begin{array}{l}\text { Volkan } \\
(2012)\end{array}$ & $\begin{array}{l}\text { He determined three factor groups for measurement of TIC of business firms: } \\
\text { 1. Input factors divided into human resources, knowledge creation and vision, } \\
\text { strategy, entrepreneurship; } \\
\text { 2. Process factors divided into Innovative organization and culture and control; } \\
\text { 3. Output factors divided into tangible returns and intellectual capital. }\end{array}$ \\
\hline $\begin{array}{l}\text { Cheng and } \\
\text { Lin (2012) }\end{array}$ & $\begin{array}{l}\text { They proposed seven main criteria for evaluating TIC implementation and } \\
\text { performance: } \\
\text { 1. Planning and commitment of the management; } \\
\text { 2. Marketing; } \\
\text { 3. Innovation; } \\
\text { 4. Knowledge and skills; } \\
\text { 5. External environment; } \\
\text { 6. Information and communication; } \\
\text { 7. Operations. }\end{array}$ \\
\hline
\end{tabular}


Table 2 summarizes assessment criteria according to previous studies reviewed:

Table 2. TIC criteria according to the literature review

\begin{tabular}{|c|c|}
\hline TIC assessment criteria & Scholars \\
\hline Percentage of R\&D personnel in a firm's workforce. & $1,2,3,4,5$ \\
\hline The labour productivity and production staff quality level. & 1,3 \\
\hline Cultivating learning consciousness and investing on learning. & 5 \\
\hline Fundraising ability. & 1 \\
\hline $\begin{array}{l}\text { Steady capital supplementation in innovation activities and the amount of R\&D } \\
\text { investment. }\end{array}$ & 3,5 \\
\hline The output value of new product. & 2,3 \\
\hline Return on investment. & 1 \\
\hline Success rate of R\&D products and commercialization success rate. & $1,4,5$ \\
\hline $\begin{array}{l}\text { Degree of new product competitiveness and understanding competitors, core } \\
\text { technology competence. }\end{array}$ & $1,4,5$ \\
\hline Forecasting and evaluating technological innovation. & 1 \\
\hline Monitoring the market forces. & $1,4,5$ \\
\hline Definition of technological innovation strategy. & $1,4,5$ \\
\hline $\begin{array}{l}\text { The level of enthusiasm and willingness for innovation of the top, middle and } \\
\text { lower management, and organization's white-collar and blue-collar employees in } \\
\text { the organization. }\end{array}$ & 2 \\
\hline $\begin{array}{l}\text { R\&D knowledge sharing ability and facilitating communication among R\&D } \\
\text { personnel. }\end{array}$ & $1,4,5$ \\
\hline Attention to tacit knowledge. & 5 \\
\hline Intensity of collaboration with other firms or R\&D centers. & 1,5 \\
\hline $\begin{array}{l}\text { The frequency that organization takes part in national and international fairs which } \\
\text { provide opportunity of promoting the new products (goods/services) in the market. }\end{array}$ & 2 \\
\hline The degree of innovativeness of R\&D ideas. & 1 \\
\hline Cross-functional screening of new R\&D project plans. & 5 \\
\hline Number of patents/ useful model certificates. & $1,2,4$ \\
\hline $\begin{array}{l}\text { The percentage (if there is any) of completing the innovation projects within the } \\
\text { specified duration, budget and quality standards by the organization during the last } \\
\text { four years. }\end{array}$ & 2,5 \\
\hline $\begin{array}{l}\text { The frequency of receiving feedback on implemented innovation creation projects } \\
\text { from the suppliers, customers, research institutes and universities and specialist } \\
\text { establishments on intellectual property rights. }\end{array}$ & 2 \\
\hline $\begin{array}{l}\text { The level that society, customers, suppliers, competitors, partners and } \\
\text { organizational management itself appreciates innovation capacity of the } \\
\text { organization. }\end{array}$ & 2 \\
\hline Re-innovation ability facing the international market. & 5 \\
\hline $\begin{array}{l}\text { Whether the organization has received any national and international innovation } \\
\text { awards. }\end{array}$ & 2 \\
\hline
\end{tabular}

Note: Wang et al. $(2008)=1$; Volkan $(2012)=2$; Heng $(2011)=3$; Cheng and Lin $(2012)=4$;

Guan et al. $(2006)=5$. 


\section{Methodology}

\subsection{Proposed model}

Figure 1 presents the steps of the proposed model to identify the relationship between TICs criteria in RTOs. After defining the problem statement, the initial list of TICs measurement sub-criteria through an extensive literature review is prepared. To determine the TIC criteria for RTOs, an expert panel for content validation and determining the suitable criteria and sub-criteria is held. An interview questionnaire was constructed and interview sessions were organized. The experts picked their favourite criteria, and after sharing with the group the similar ones were entered to the final list, which at the final round were again discussed and finalized. To analyze the expert opinion about the cause and effect relationships the Fuzzy-DEMATEL method were utilized. Finally the results were discussed through an expert panel.

All the experts of the panel have had remarkable experiences in executing research and technology projects in national and international level; in this regard they have used their expertise and experience to elicit some limited criteria which have been the main causes of success in their projects. All chosen criteria in literature review are sent to panel and they have analysed the criteria and then extracted the final list which is shown in Table 3. The final list takes a holistic approach to innovation capability by not focusing only in some parts; but also all the sections required to absorb and use the innovation.

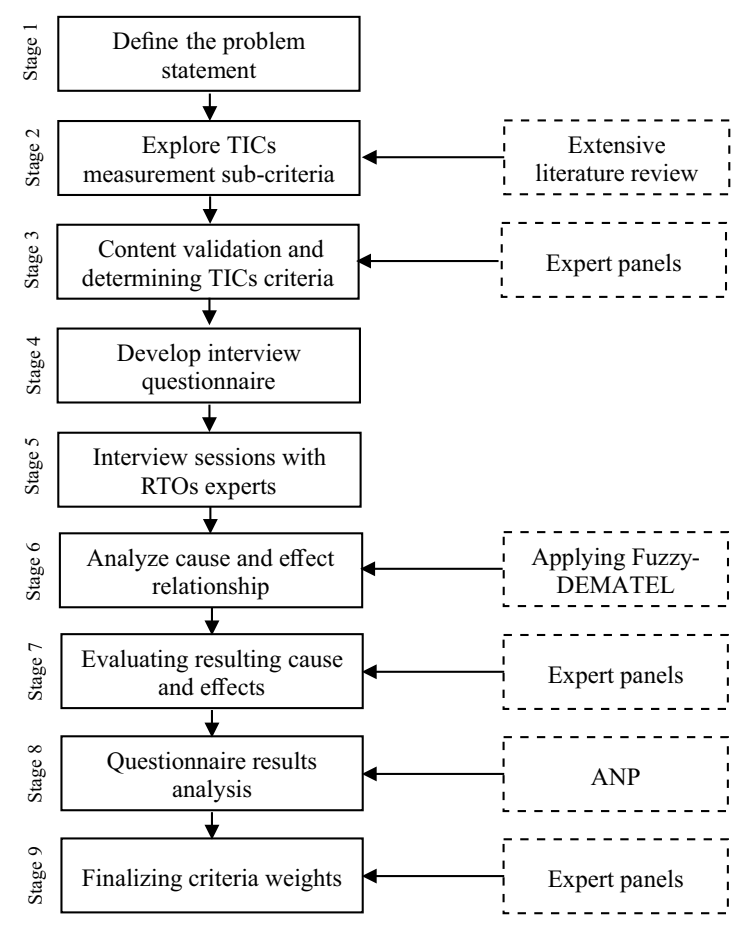

Fig. 1. The steps of the proposed model 
Table 3. Finalized TIC criteria and sub-criteria selected for RTOs

\begin{tabular}{|c|c|}
\hline Criteria & Sub-criteria \\
\hline \multirow{2}{*}{ Collective learning (CL) } & Professional training \\
\hline & Knowledge management \\
\hline \multirow{2}{*}{ Resource (R) } & Ability of absorbing financial resources \\
\hline & Percentage of creative workers \\
\hline \multirow{2}{*}{ Marketing (M) } & Competitiveness \\
\hline & Specific marketing \\
\hline \multirow{7}{*}{ Innovation organizing (IO) } & Systematic development of technology \\
\hline & Intensity of collaboration with other firms or $\mathrm{R} \& \mathrm{D}$ centres \\
\hline & Frequency of receiving feedback \\
\hline & Facilitating inter-organizational relationships \\
\hline & Innovation in human resource procedures \\
\hline & Innovation culture \\
\hline & Management of intellectual property rights \\
\hline Strategic planning (SP) & Strategic planning \\
\hline \multirow{4}{*}{ Performance (P) } & Number of commercialized technologies \\
\hline & Number of patents filling and published papers \\
\hline & Number of national and international innovation awards \\
\hline & Success rate of innovative projects \\
\hline
\end{tabular}

\subsection{DEMATEL technique}

The Battelle Memorial Institute of Geneva introduced DEMATEL in order to solve complex problems visually (Gabus, Fontela 1972). The main specific of this technique is to improve the understanding of the causal relationships among the variables by presenting graphical cause and effect relationships (Pourahmad et al. 2015). The procedure of this technique is explained step by step below in step 1 to 4 (Fontela, Gabus 1976a, 1976b).

Step 1: Generating the direct-relation matrix. For measuring the relationship a scale of 5 items is introduced from 0 to 4 :

- No influence (0),

- Very low influence (1),

- Low influence (2),

- High influence (3),

- Very high influence (4).

Next, decision makers prepare sets of the pair-wise comparisons in terms of effects and direction between criteria. Then the initial data can be obtained as the direct-relation matrix which is an $n \times n$ matrix $A$ where each element of $a_{i j}$ is denoted as the degree in which the criteria $i$ affects the criteria $j$.

Step 2: Normalizing the direct-relation matrix. Normalization is performed using the following:

$$
X=s \times A,
$$




$$
s=\min \left(\frac{1}{\max _{1 \leq i \leq n} \sum_{j=1}^{n}\left[a_{i j}\right]}, \frac{1}{\max _{1 \leq j \leq n} \sum_{i=1}^{n}\left[a_{i j}\right]}\right), \quad i, j=1,2, \ldots, n .
$$

Step 3: Deriving the total-relation matrix. The total relation matrix $T$ acquired

$$
T=X(I-X)^{-1},
$$

where: $I$ - identity matrix.

Step 4: Producing a causal diagram. The sum of rows and the sum of columns are separately denoted as vector $D$ and vector $R$ through. Then, the horizontal axis vector $(D+R)$ named "Prominence" is made by adding $D$ to $R$, which reveals the relative importance of each criteria. Similarly, the vertical axis $(D-R)$ named "Relation" is made by subtracting $R$ from $D$, which may divide criteria into a cause and effect groups. Generally, when $(D-R)$ is positive, the criteria belongs to the cause group and when the $(D-R)$ is negative, the criteria represents the effect group.

$$
\begin{gathered}
T=\left[t_{i j}\right]_{n \times n}, i, j=1,2, \ldots, n ; \\
R=\left[\sum_{j=1}^{n} t_{i j}\right]=\left[r_{i .}\right]_{n \times 1} ; \\
D=\left[\sum_{i=1}^{n} t_{i j}\right]_{1 \times n}=\left[d_{j}\right]_{1 \times n} .
\end{gathered}
$$

The causal diagram can be obtained by mapping the dataset of the $(D+R, D-R)$. The findings can provide some insights allowing RTOs to improve their TIC performance based on the criteria that most significantly influences the performance of other criteria.

\subsection{Triangular fuzzy numbers}

Zadeh is the founder of fuzzy set theory which deals with linguistic variable problems in the real world. A triangular fuzzy number $\tilde{\mathrm{A}}$ is shown as a triplet $(l, m, r)$ and also shown in Figure 2 (Zadeh 1965). Fuzzy numbers refer to the fuzzy set on real line $R$ and their membership function is $\mu_{\mathrm{x}}(Y): R \rightarrow[0,1]$.

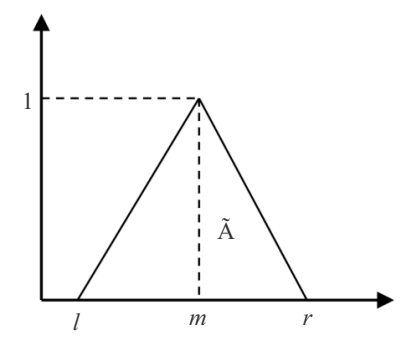

Fig. 2. A triangle fuzzy number 
If we assess a project satisfaction with a clear and precise number, it is less likely to reflect the reality. Therefore, fuzzy numbers are used instead to show the degree of satisfaction. Fuzzy aggregation processes must include a defuzzification step too. The Converting Fuzzy data into Crisp Scores (CFCS) defuzzication method for our fuzzy aggregation procedure is applied. This approach is supposed to be more effective by researchers for arriving at crisp values (e.g. when compared to the Centroid method) (Opricovic, Tzeng 2003).

\subsection{DANP model}

The influential weights of DANP (DEMATEL-ANP) contains the following steps (Peng, Tzeng 2013; Pourahmad et al. 2015).

Step 1: Model construction and problem structure. The questions are clearly described then break them down to level structure.

Step 2: Establish the weightless super matrix. The total relation matrix $T$ shown in Eq. (7) is received from DEMATEL. Each column will be summed up for normalization.

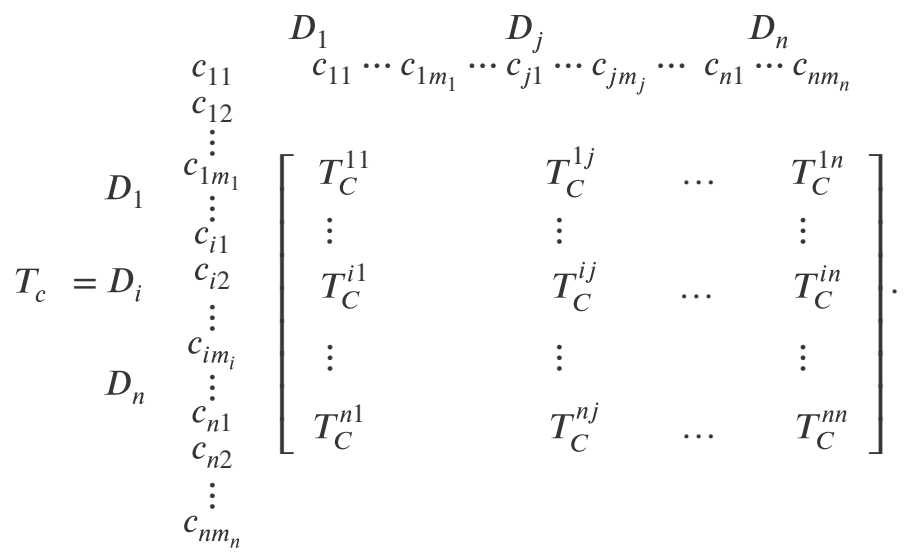

After normalizing the total relation matrix $T_{C}$ by dimensions, will obtain a new matrix $T_{C}^{\alpha}$, shown as Eq. (8).

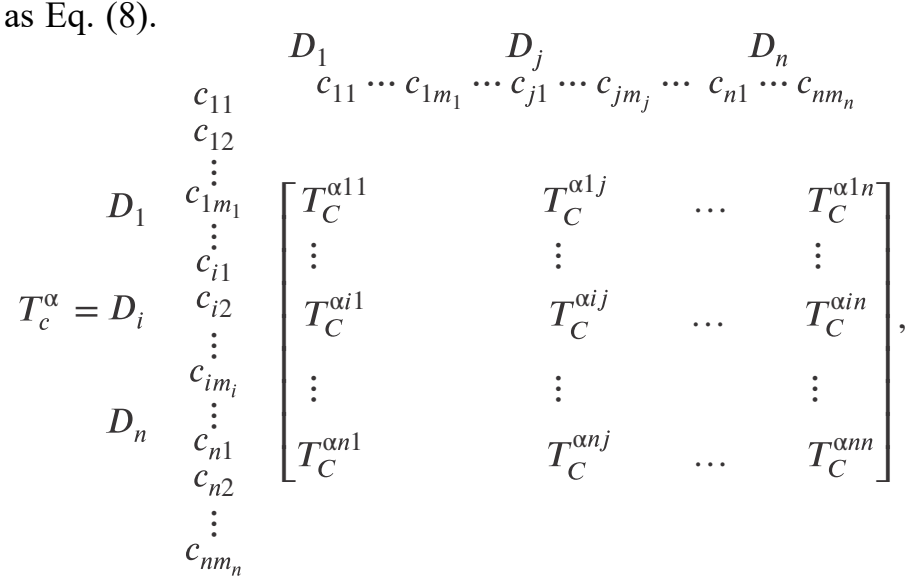

where: $T_{C}^{\alpha 11}$ is obtained as Eqs (9) and (10), and other $T_{C}^{\alpha n m}$ values are as below. 


$$
\begin{gathered}
d_{c i}^{11}=\sum_{j=1}^{m_{1}} t_{c i j}^{11}, i=1,2, \ldots, m_{1}, \\
T_{C}^{\alpha 11}=\left[\begin{array}{lllll}
t_{C 11}^{11} / d_{C 1}^{11} & \cdots & t_{C 1 j}^{11} / d_{C 1}^{11} & \cdots & t_{C 1 m_{1}}^{11} / d_{C 1}^{11} \\
\vdots & & \vdots & \vdots \\
t_{C i 1}^{11} / d_{C i}^{11} & \cdots & t_{C i j}^{11} / d_{C i}^{11} & \cdots & t_{C i m_{1}}^{11} / d_{C i}^{11} \\
\vdots & & & \vdots \\
t_{C m_{1} 1}^{11} / d_{C 1}^{11} & \cdots & t_{C m_{1} j}^{11} / d_{C m_{1}}^{11} & \cdots & t_{C m_{1} m_{1}}^{11} / d_{C m_{1}}^{11}
\end{array}\right]=\left[\begin{array}{lllll}
t_{C 11}^{\alpha 11} & \cdots & t_{C 1 j}^{\alpha 11} & \cdots & t_{C 1 m_{1}}^{\alpha 11} \\
\vdots & & \vdots & \vdots \\
t_{C i 1}^{\alpha 11} & \cdots & t_{C i j}^{\alpha 11} & \cdots & t_{C i m_{1}}^{\alpha 11} \\
\vdots & & \vdots & \\
t_{C m_{1} 1}^{\alpha 11} & \cdots & t_{C m_{1} j}^{\alpha 11} & \cdots & t_{C m_{1} m_{1}}^{\alpha 11}
\end{array}\right] .
\end{gathered}
$$

To acquire the weightless super matrix, use the interdependent relationship in the group to array $T_{C}^{\alpha}$ by dimensions, i.e., $W=\left(T_{C}^{\alpha}\right)^{\prime}$ (Eq. 11).

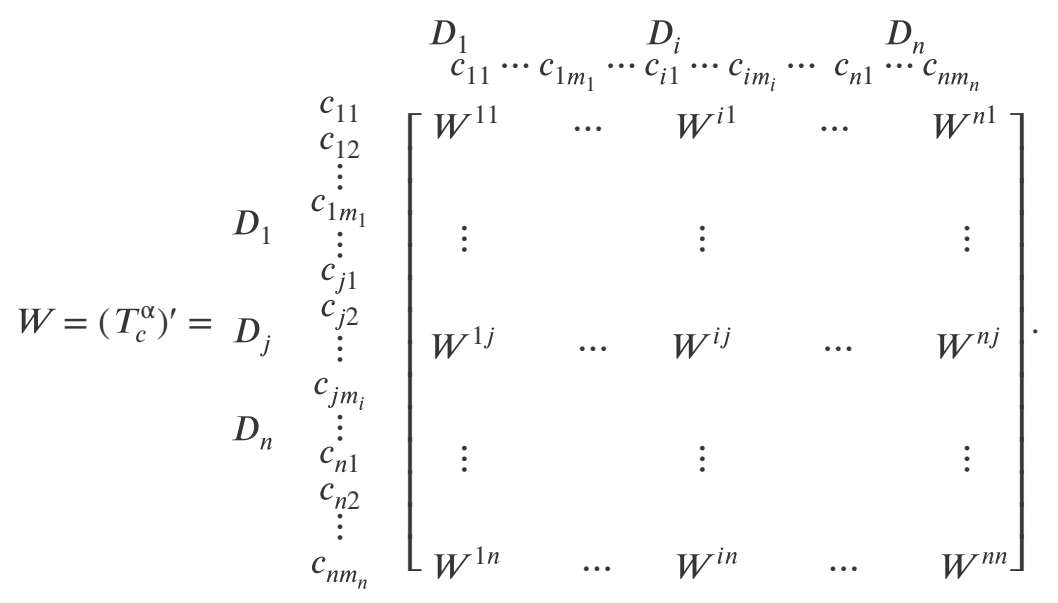

If the matrix $W^{11}$ is blank or 0 as shown in Eq. (12), this means that the matrix between the criteria is independent and with no interdependence, and the other $W^{n n}$ value is as given below:

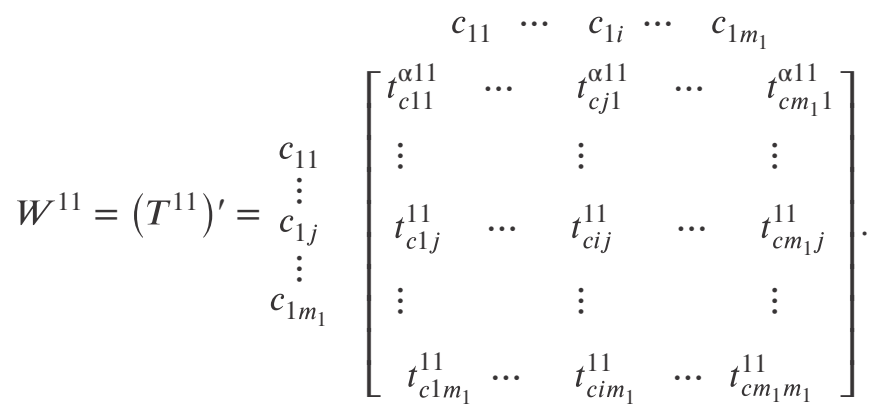

Step 3: Obtain the weighted super matrix by normalizing the sum of impact for each hierarchy and each dimension in the dimensions total relation matrix as illustrated in Eq. (13): 


$$
T_{D}=\left[\begin{array}{lllll}
t_{D}^{11} & \cdots & t_{D}^{1 j} & \cdots & t_{D}^{1 n} \\
\vdots & & \vdots & & \vdots \\
t_{D}^{i 1} & \cdots & t_{D}^{i j} & \cdots & t_{D}^{i n} \\
\vdots & & \vdots & & \vdots \\
t_{D}^{n 1} & \cdots & t_{D}^{n j} & \cdots & t_{D}^{n n}
\end{array}\right]
$$

Normalizing the total relation matrix $T_{D}$ yields $T_{D}^{\alpha}$ as follows (Eqs.14 and 15).

$$
\begin{aligned}
& \left(T_{D}^{\alpha i j}=T_{D}^{i j} / d_{i}\right), \\
& T_{D}^{\alpha}=\left[\begin{array}{ccccc}
t_{D}^{11} / d_{1} & \cdots & t_{D}^{1 j} / d_{1} & \cdots & t_{D}^{1 n} / d_{1} \\
t_{D}^{i 1} / d_{2} & \cdots & t_{D}^{i j} / d_{2} & \cdots & t_{D}^{i n} / d_{2} \\
t_{D}^{n 1} / d_{3} & \cdots & t_{D}^{n j} / d_{3} & \cdots & t_{D}^{n n} / d_{3}
\end{array}\right]=\left[\begin{array}{lllll}
t_{D}^{\alpha 11} & \cdots & t_{D}^{\alpha 1 j} & \cdots & t_{D}^{\alpha 1 n} \\
\vdots & & \vdots & & \vdots \\
t_{D}^{\alpha i 1} & \cdots & t_{D}^{\alpha i j} & \cdots & t_{D}^{\alpha i n} \\
\vdots & & \vdots & & \vdots \\
t_{D}^{\alpha n 1} & \cdots & t_{D}^{\alpha n j} & \cdots & t_{D}^{\alpha n n}
\end{array}\right] .
\end{aligned}
$$

Let the normalized total relation matrix $T_{D}^{\alpha}$ fill into the weightless super matrix to obtain the weighted super matrix (Eq. 16):

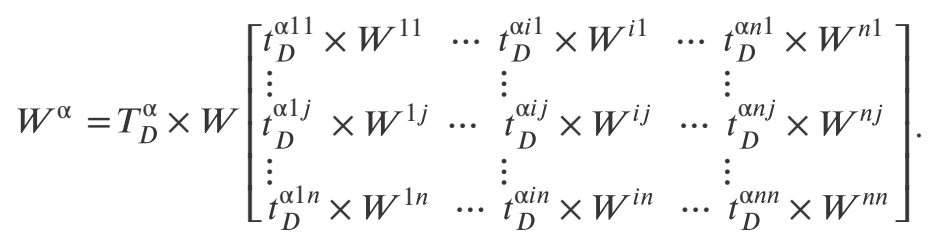

Step 4: Limit the weighted super matrix. Obtain the limited super matrix, or the influential weight of each criteria, by multiple productions of the weighted super matrix as $\lim _{\varphi \rightarrow \infty}=\left(W^{\alpha}\right)^{\varphi}$. That is to say, the influential weights of DANP are acquired by the limit super matrix $W^{\alpha}$ with power $\varphi$, indicating any figure for power.

\subsection{Questionnaire analysis}

The required data for performing the Fuzzy-DEMATEL technique is obtained by circulating a questionnaire which is validated by professions experts of the petroleum industry who all of them have more than 10 years of experience in oil industry of Iran including of researchers, engineers and division/section managers. Table 4 presents an

\begin{tabular}{|c|c|c|c|c|c|c|}
\hline TIC Criteria & CL & $\mathrm{R}$ & $\mathrm{M}$ & IO & SP & $P$ \\
\hline $\mathrm{CL}$ & $\uparrow$ & & & & & \\
\hline $\mathrm{R}$ & & & & & & \\
\hline $\mathrm{M}-$ & $\rightarrow$ & & & & & \\
\hline IO & & & & & & \\
\hline SP & & & & & & \\
\hline $\mathrm{P}$ & & & & & & \\
\hline
\end{tabular}
example of this questionnaire. Each respondent chose an integer scale from 0 to 4 explained in the first step of DEMATEL technique:

Table 4. Generic questionnaire used for DEMATEL technique in this study 
This process leads to a visual diagram named as Influence Relations Map (IRM) which is then turned to fuzzy numbers by the Table 5 change structure:

Table 5. Fuzzy numbers used in internal connections computations

\begin{tabular}{cc}
\hline Linguistic variables & Fuzzy numbers \\
\hline Very high effective & $(3,3,4)$ \\
\hline High effective & $(2,3,4)$ \\
\hline Low effective & $(1,2,3)$ \\
\hline Very low effective & $(0,1,2)$ \\
\hline Without any effect & $(1,2,2)$ \\
\hline
\end{tabular}

Table 6 shows reliability analysis. Cronbach's Alpha is applied to test the reliability of the data collected from the questionnaire. As Alpha for all criteria exceeds 0.7 ; test results reveal that the questionnaire is reliable.

Table 6. Reliability tests for the questionnaire

\begin{tabular}{lc}
\hline \multicolumn{1}{c}{ Tests } & Cronbach's Alpha \\
\hline Data on criteria & 0.91 \\
\hline Data on resource sub-criteria & 0.89 \\
\hline Data on marketing sub-criteria & 0.81 \\
\hline Data on innovation organizing sub-criteria & 0.93 \\
\hline Data on strategic planning sub-criteria & 0.84 \\
\hline Data on performance sub-criteria & 0.87 \\
\hline Data on collective learning sub-criteria & 0.91 \\
\hline
\end{tabular}

\section{Results}

\subsection{Analysis of the results of DEMATEL}

Figure 3 shows the cause and effect diagrams among TIC criteria. As it is depicted, SP and $C L$ are in cause group and strongly affect all other criteria. So an improvement in Strategic planning and Collective learning has an important role in any TIC improve-

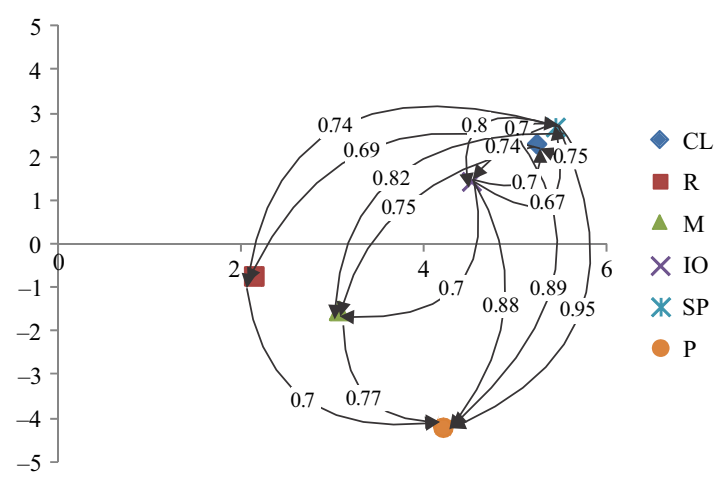

Fig. 3. Cause-effect relationship among TICs criteria 
ment strategy. Results also show that Innovation organizing is the only criteria that influence CL and SP. In order to make causal diagram based on step 4 of DEMATEL technique Table 7 is developed:

Table 7. Total influence of each one of the criteria

\begin{tabular}{lcccc}
\hline \multicolumn{1}{c}{ Criteria } & $d$ & $r$ & $d+r$ & $d-r$ \\
\hline Collective learning (CL) & 3.77 & 1.46 & 5.22 & 2.31 \\
\hline Resource (R) & 0.70 & 1.43 & 2.13 & -0.73 \\
\hline Marketing (M) & 0.77 & 2.29 & 3.06 & -1.52 \\
\hline Innovation organizing (IO) & 2.98 & 1.53 & 4.51 & 1.44 \\
\hline Strategic planning (SP) & 4.06 & 1.37 & 5.43 & 2.69 \\
\hline Performance (P) & 0.00 & 4.20 & 4.20 & -4.20 \\
\hline
\end{tabular}

The cause and effect relationship among every TIC sub-criteria are shown in Figure 4 to Figure 8. Professional learning and Knowledge management are the sub-criteria of CL which have a direct influence on each other.

Figure 5 shows the cause and effect relationship among Resource sub-criteria. As it is shown Funding ability is in cause group while the Percentage of creative personal is in effect group.

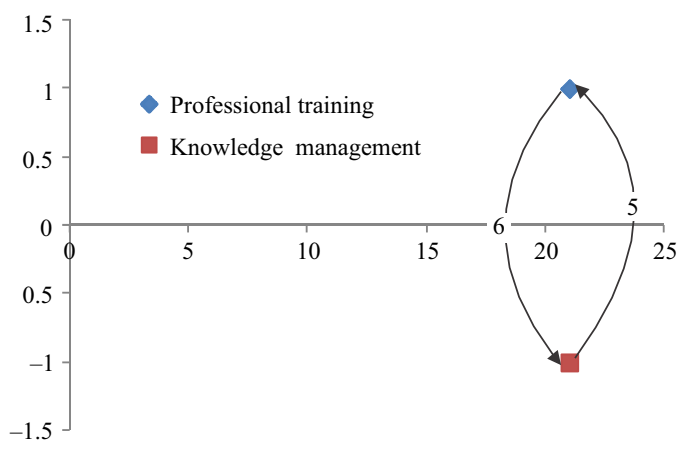

Fig. 4. Cause-effect relationship among CL sub-criteria

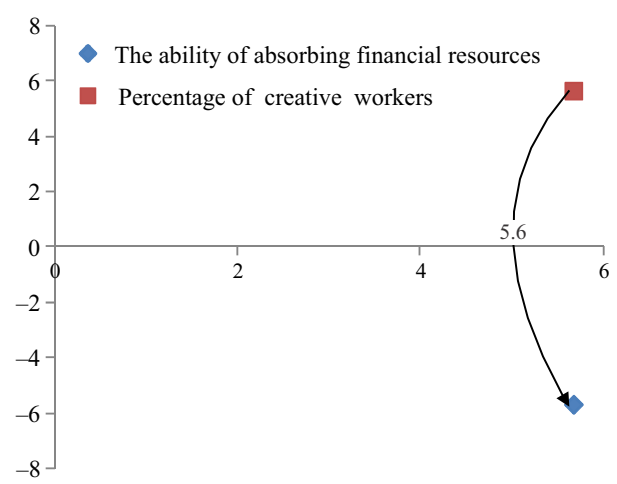

Fig. 5. Cause-effect relationship among R sub-criteria 
Among Marketing sub-criteria, the Competitiveness has a cause relation with Specific marketing (Fig. 6).

Figure 7 shows the relationship among Performance sub-criteria. As it is depicted, while the Innovation projects success factor affects all other Performance sub-criteria, it may not affected by any other sub-criteria. So, to improve TICs in a research and technology organization Projects success factor should be taken into consideration. The number of patents and published papers affects the Number of national and international innovation awards. These latter criteria increase the credibility of the organization and so cause in the organization success in technology commercialization.

The relationship among Innovation organizing sub-criteria is shown in Figure 8. Among these sub-criteria Systematic development of technology and the culture of innovation have a mutual cause and effect relationship with other sub-criteria and so are relatively more important indicators. The Intensity of collaboration with other firms or R\&D centers is also a cause factor while the Management of intellectual property rights is mainly an effect factor.

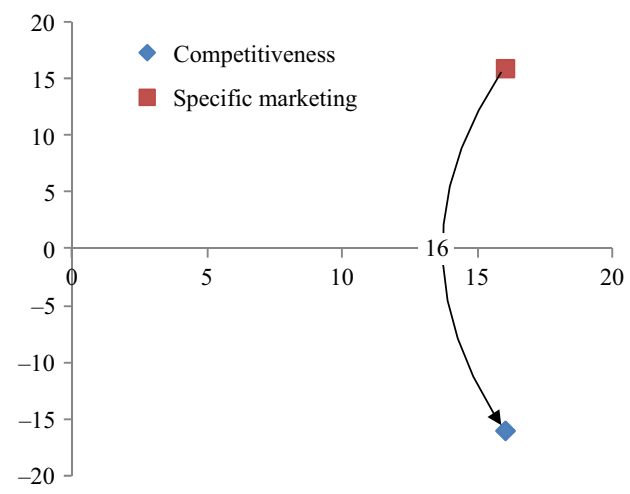

Fig. 6. Cause-effect relationship among $M$ sub-criteria

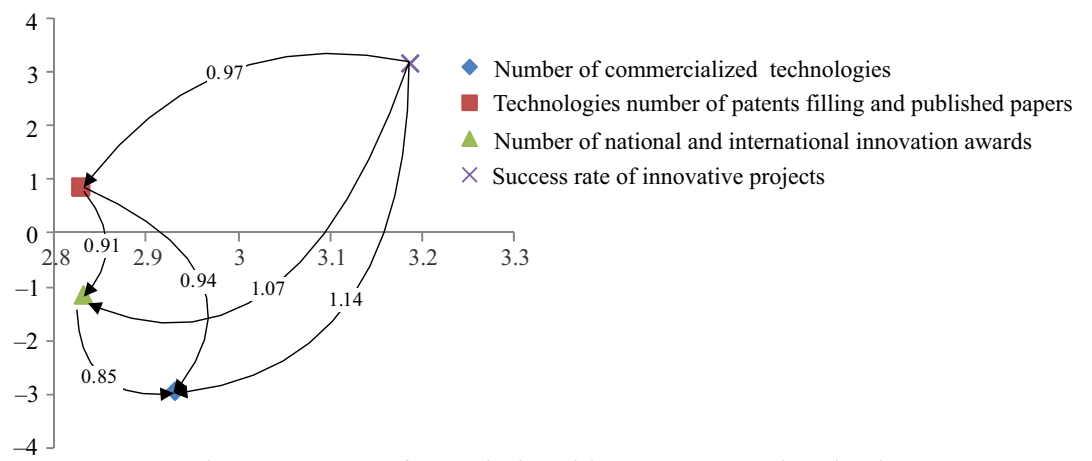

Fig. 7. Cause-effect relationship among P sub-criteria 


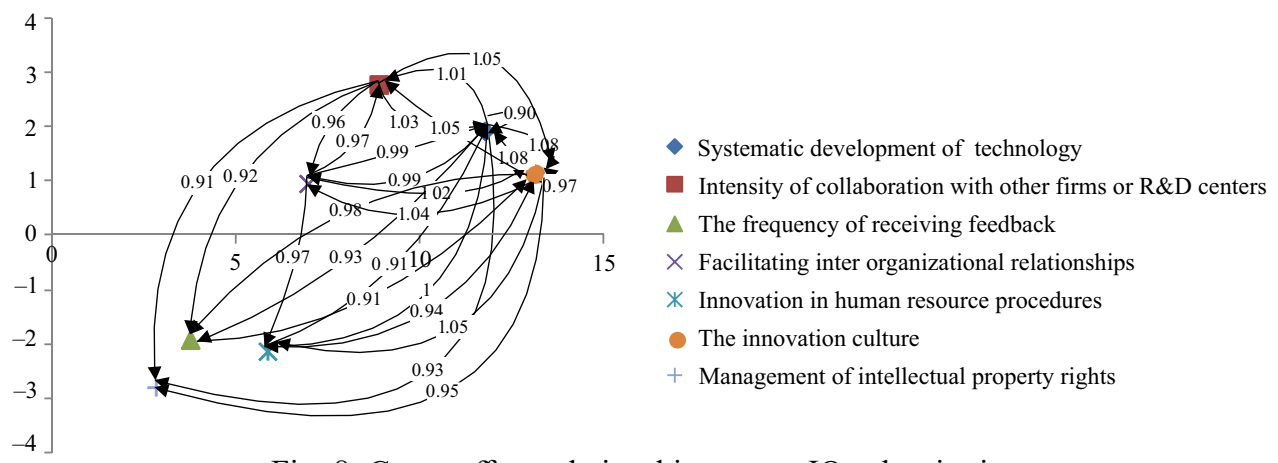

Fig. 8. Cause-effect relationship among IO sub-criteria

\subsection{Application of DANP}

Identifying the causal relations in the previous step by DEMATEL has led to network relations determination. In order to measure criteria and sub-criteria weights we have used ANP (Saaty 1996; Lin, Pan 2014) by using Super Decision software.

DEMATEL technique up to now has shown the interconnections intensity between each group of criteria and sub criteria, however to obtain the weight among them, we need to apply a MCDM technique. ANP is able to work in complex conditions when assumed there are interconnections among criteria, while AHP is only used when assumed criteria are independent (Pak 2011; Ferreita et al. 2014; Adnan et al. 2015). ANP technique is required to complete the paper results since the weight is needed to make the decision; in many similar studies such as Büyüközkan and Güleryüz (2016), Chen (2016) in order to complete the results of DEMATEL for decision makers ANP is used to find out the weight of each sub criteria to the criteria. DEMATEL is quite sufficient to analyze cause and effect relationship, yet it is not able to weight the criteria, so by combining a useful and more comprehensive tool is created. According to Horng et al. (2014), DEMATEL and ANP methods together lead to create a combined tool which compensate each other weakness and help decision makers to calculate the weights of the business environment criteria. In this regard, a questionnaire is structured and distributed to 16 experts. Tables 8 to 14 show the results obtained for ANP technique.

In order to do this technique firstly we need to make a weightless super matrix which is shown in Table 8. This table shows the impact of each criteria to TIC. After that a limited super matrix is developed which is shown in Table 9. Finally, for 5 criteria, the main 6 criteria except strategic planning, are provided to show the weights. Strategic planning is not found to have any sub criteria by the expert's panel, so it is vestigial to show any table for this criteria. Table 9 is the limited super matrix respective Table 8 . In Tables 10 to 14 limited super matrixes for each cluster and its respective sub criteria except for strategic planning are presented. 
Table 8. Weightless super matrix for TICs criteria

\begin{tabular}{|c|c|c|c|c|c|c|c|c|}
\hline \multirow{2}{*}{\multicolumn{2}{|c|}{$\begin{array}{l}\text { Cluster node } \\
\text { labels }\end{array}$}} & \multirow{2}{*}{$\frac{\text { GOAL }}{\text { TIC }}$} & \multicolumn{6}{|c|}{ Model } \\
\hline & & & CL & $\mathrm{R}$ & M & IO & SP & $\mathrm{P}$ \\
\hline GOAL & TIC & 0.000000 & 0.000000 & 0.000000 & 0.000000 & 0.000000 & 0.000000 & 0.000000 \\
\hline \multirow{6}{*}{$\begin{array}{l}\frac{\overline{0}}{\overline{0}} \\
\stackrel{0}{\Sigma}\end{array}$} & $\mathrm{CL}$ & 0.189030 & 0.000000 & 0.000000 & 0.169200 & 0.200000 & 0.200000 & 0.247887 \\
\hline & $\mathrm{R}$ & 0.128630 & 0.000000 & 0.000000 & 0.00000 & 0.000000 & 0.000000 & 0.134434 \\
\hline & $\mathrm{M}$ & 0.035602 & 0.000000 & 0.000000 & 0.00000 & 0.000000 & 0.000000 & 0.165809 \\
\hline & $\mathrm{IO}$ & 0.043361 & 0.200000 & 0.666667 & 0.387371 & 0.000000 & 0.800000 & 0.096448 \\
\hline & SP & 0.293480 & 0.800000 & 0.333333 & 0.443429 & 0.800000 & 0.000000 & 0.355422 \\
\hline & $P$ & 0.309964 & 0.000000 & 0.000000 & 0.000000 & 0.000000 & 0.000000 & 0.000000 \\
\hline
\end{tabular}

Table 9. Limited super matrix for TICs criteria

\begin{tabular}{|c|c|c|c|c|c|c|c|c|}
\hline \multirow{2}{*}{\multicolumn{2}{|c|}{$\begin{array}{l}\text { Cluster node } \\
\text { labels }\end{array}$}} & \multirow{2}{*}{$\begin{array}{c}\text { GOAL } \\
\text { TIC }\end{array}$} & \multicolumn{6}{|c|}{ Model } \\
\hline & & & $\mathrm{CL}$ & $\mathrm{R}$ & M & IO & SP & $\mathrm{P}$ \\
\hline GOAL & TIC & 0.000000 & 0.000000 & 0.000000 & 0.000000 & 0.000000 & 0.000000 & 0.000000 \\
\hline \multirow{6}{*}{$\begin{array}{l}\overline{0} \\
\sum^{0}\end{array}$} & $\mathrm{CL}$ & 0.166667 & 0.166667 & 0.166667 & 0.166667 & 0.166667 & 0.166667 & 0.166667 \\
\hline & $\mathrm{R}$ & 0.000000 & 0.000000 & 0.000000 & 0.000000 & 0.000000 & 0.000000 & 0.000000 \\
\hline & M & 0.000000 & 0.000000 & 0.000000 & 0.000000 & 0.000000 & 0.000000 & 0.000000 \\
\hline & IO & 0.388889 & 0.388889 & 0.388889 & 0.388889 & 0.388889 & 0.388889 & 0.388889 \\
\hline & SP & 0.444444 & 0.444444 & 0.444444 & 0.444444 & 0.444444 & 0.444444 & 0.444444 \\
\hline & $P$ & 0.000000 & 0.000000 & 0.000000 & 0.000000 & 0.000000 & 0.000000 & 0.000000 \\
\hline
\end{tabular}

Table 10. Limited super matrix for Collective learning criteria

\begin{tabular}{|c|c|c|c|c|}
\hline \multirow{2}{*}{\multicolumn{2}{|c|}{ Cluster node labels }} & \multicolumn{2}{|c|}{ Sub-criteria } & \multirow{2}{*}{$\begin{array}{c}\text { Criteria } \\
\mathrm{CL}\end{array}$} \\
\hline & & Professional training & Knowledge management & \\
\hline \multirow[b]{2}{*}{ Sub-criteria } & Professional training & 0.000000 & 0.000000 & 0.200000 \\
\hline & $\begin{array}{l}\text { Knowledge } \\
\text { management }\end{array}$ & 1.00000 & 0.000000 & 0.800000 \\
\hline Criteria & $\mathrm{CL}$ & 0.000000 & 0.000000 & 0.000000 \\
\hline
\end{tabular}

Table 11. Limited super matrix for Resource criteria

\begin{tabular}{|c|c|c|c|c|}
\hline \multirow{2}{*}{\multicolumn{2}{|c|}{ Cluster node labels }} & \multicolumn{2}{|c|}{ Sub-criteria } & \multirow{2}{*}{$\begin{array}{c}\text { Criteria } \\
\mathrm{R}\end{array}$} \\
\hline & & $\begin{array}{c}\text { Absorbing } \\
\text { resources ability }\end{array}$ & $\begin{array}{c}\text { Innovative employees } \\
\text { percentage }\end{array}$ & \\
\hline \multirow{2}{*}{ Sub-criteria } & $\begin{array}{c}\text { Absorbing resources } \\
\text { ability }\end{array}$ & 0.000000 & 1.000000 & 0.857143 \\
\hline & $\begin{array}{c}\text { Innovative employees } \\
\text { percentage }\end{array}$ & 0.000000 & 0.000000 & 0.142857 \\
\hline Criteria & $\mathrm{R}$ & 0.000000 & 0.000000 & 0.000000 \\
\hline
\end{tabular}


S. S. Mortazavi Ravari et al. Framework for assessing technological innovation capability in research ...

Table 12. Limited super matrix for Marketing criteria

\begin{tabular}{ccccc}
\hline \multirow{2}{*}{ Cluster node labels } & \multicolumn{2}{c}{ Sub-criteria } & Criteria \\
\cline { 3 - 5 } & & Competiveness & Specific marketing & $\mathrm{M}$ \\
\hline \multirow{2}{*}{ Sub-criteria } & Competiveness & 0.000000 & 1.000000 & 0.600000 \\
\cline { 2 - 5 } & Specific marketing & 0.000000 & 0.000000 & 0.400000 \\
\hline Criteria & $\mathrm{M}$ & 0.000000 & 0.000000 & 0.000000 \\
\hline
\end{tabular}

Table 13. Limited super matrix for Innovation organizing criteria

\begin{tabular}{|c|c|c|c|c|c|c|c|c|c|}
\hline \multirow{2}{*}{\multicolumn{2}{|c|}{ Cluster node labels }} & \multicolumn{7}{|c|}{ Sub-criteria } & \multirow[b]{2}{*}{$\begin{array}{c}\text { Criteria } \\
\\
\bigcirc\end{array}$} \\
\hline & & 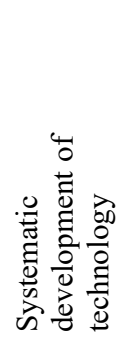 & 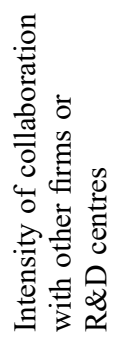 & 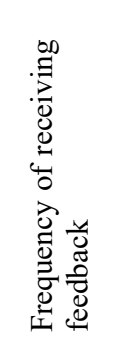 & 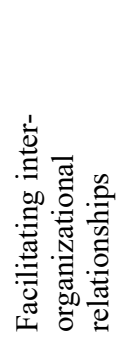 & 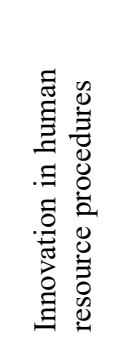 & 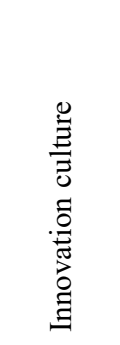 & 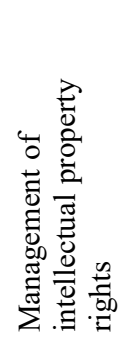 & \\
\hline \multirow{7}{*}{ 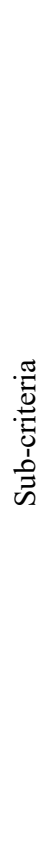 } & $\begin{array}{l}\text { Systematic } \\
\text { development } \\
\text { of technology }\end{array}$ & 0.201074 & 0.201074 & 0.201074 & 0.201074 & 0.201074 & 0.201074 & 0.201074 & 0.201074 \\
\hline & $\begin{array}{l}\text { Intensity of } \\
\text { collaboration } \\
\text { with other firms } \\
\text { or R\&D centres }\end{array}$ & 0.090890 & 0.090890 & 0.090890 & 0.090890 & 0.090890 & 0.090890 & 0.090890 & 0.090890 \\
\hline & $\begin{array}{l}\text { Frequency } \\
\text { of receiving } \\
\text { feedback }\end{array}$ & 0.038676 & 0.038676 & 0.038676 & 0.038676 & 0.038676 & 0.038676 & 0.038676 & 0.038676 \\
\hline & $\begin{array}{l}\text { Facilitating inter- } \\
\text { organizational } \\
\text { relationships }\end{array}$ & 0.146526 & 0.146526 & 0.146526 & 0.146526 & 0.146526 & 0.146526 & 0.146526 & 0.146526 \\
\hline & $\begin{array}{l}\text { Innovation in } \\
\text { human resource } \\
\text { procedures }\end{array}$ & 0.087676 & 0.087676 & 0.087676 & 0.087676 & 0.087676 & 0.087676 & 0.087676 & 0.087676 \\
\hline & $\begin{array}{l}\text { Innovation } \\
\text { culture }\end{array}$ & 0.435158 & 0.435158 & 0.435158 & 0.435158 & 0.435158 & 0.435158 & 0.435158 & 0.435158 \\
\hline & $\begin{array}{l}\text { Management } \\
\text { of intellectual } \\
\text { property rights }\end{array}$ & 0.00000 & 0.00000 & 0.00000 & 0.00000 & 0.00000 & 0.00000 & 0.00000 & 0.000000 \\
\hline. & IO & 0.00000 & 0.00000 & 0.00000 & 0.00000 & 0.00000 & 0.00000 & 0.00000 & 0.000000 \\
\hline
\end{tabular}


Table 14. Limited super matrix for Performance criteria

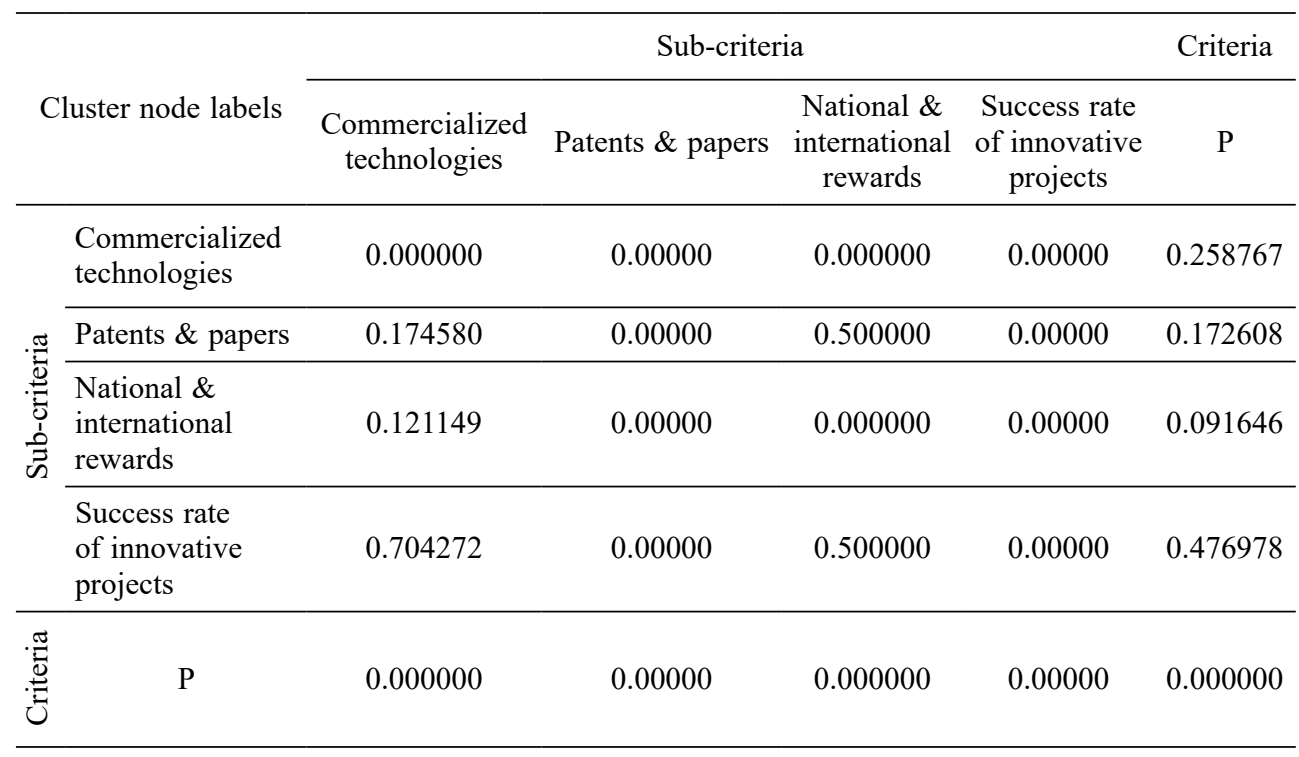

\section{Conclusions}

The main aim of this study is to identify the effective factors in formation of technologic innovation capabilities in research and technology organizations. A comprehensive model is developed and then evaluated in a RTO in petroleum industry sector of Iran. In this model fuzzy DEMATEL and ANP are used in order to analysis the causal relations and identifying the intensity of these relations; and at last criteria and sub-criteria are weighted. The model proposed in this paper is helpful for any organization concerned about its capability to make innovation; hence it can be applied by RTOs to understand their own criteria to build up innovation capability.

The results of this model suggest to managers of our concerned RTO that they should focus more on some criteria such as strategic planning and innovative organizing. However after analysing the importance of all criteria it is concluded that performance and strategic planning, more than any other one, can lead to technologic innovation capabilities in RTOs. We have identified that number of commercialized technologies, and success rate of innovative projects, and ability of absorbing financial resources among all sub criteria are more important than the other parameters.

This model uses a step by step process and helps to have a systematic approach for identifying the most important criteria for technology innovation by using a rarely used combination of fuzzy DEMATEL and ANP for this goal. Using the combination of these two techniques helps organizations reach to valid criteria, since they are able to consider mutual relationships among different criteria; the results of this study is important as they can set their future strategies for improving technology innovation. As we have studied in literature reviews of the field, each organization might consider some diffe- 
rent criteria to assess its capability in technology innovation; based on this approach we have suggested a model which can be adopted by any RTO to have a simple step by step procedure to find out its own criteria which only can be reached by considering its own concerns and limits. However the criteria provided in this paper can be common in other organizations but surely they are different in general based on the industry and the type of the organization. In this way; the main contribution of this paper is to propound a model composed of right techniques and steps toward making a customized set of weighted criteria for any RTO. Furthermore, DEMATEL as the main technique used in this model provides an efficient way of understanding the inner relation between the criteria and their impact level on each other which leads to a final true selection.

The available professionals who can understand the real necessities of oil industry in regard with the TICs are few so that it limited amount of experts used in the research. Using more diverse groups can lead to a better understanding of the issue.

The future opportunity to extend the application of this research is to apply the same framework in other RTOs and investigate the quality of the results. Also it is possible to use other methodologies to compare their results with the result of this model.

\section{References}

Adler, P. S.; Shenbar, A. 1990. Adapting your technological base: the organizational challenge, Sloan Management Review 25: 25-37.

Adnan, Y. M.; Daud, M. N.; Mohamed Razali, M. N. 2015. A multi-criteria framework for office tenants' preferences at office buildings, International Journal of Strategic Property Management 19(3): 271-282. http://dx.doi.org/10.3846/1648715X.2015.1052586

Amara, N.; Landry, R. 2005. Sources of information as determinants of novelty of innovation in manufacturing firms. Evidence from the 1999 statistics Canada innovation survey, Technovation 25: 245-259. http://dx.doi.org/10.1016/S0166-4972(03)00113-5

Arnold, E.; Rush, H.; Bessant, J.; Hobday, M. 1998. Strategic planning in research and technology institutes, R\&D Management 28(2): 89-100. http://dx.doi.org/10.1111/1467-9310.00085

Barge-Gil, A; Modrego, A. 2011. The impact of research and technology organizations on firm competitiveness: measurement and determinants, Journal of Technology Transfer 36(1): 61-83. http://dx.doi.org/10.1007/s10961-009-9132-4

Boly, V.; Morel, L.; Assielou, N. G.; Camargo, M. 2014. Evaluating innovative processes in French firms: methodological proposition for firm innovation capacity evaluation, Research Policy 43(3): 608-622. http://dx.doi.org/10.1016/j.respol.2013.09.005

Burgelman, R.; Maidique, M. A.; Wheelwright, S. C. 2004. Strategic management of technology and innovation. New York: McGraw-Hill.

Büyüközkan, G.; Güleryüz, S. 2016. An integrated DEMATEL-ANP approach for renewable energy resources selection in Turkey, International Journal of Production Economics 182: 435-448. http://dx.doi.org/10.1016/j.ijpe.2016.09.015

Camisón, C.; Villar-López, A. 2014. Organizational innovation as an enabler of technological innovation capabilities and firm performance, Journal of Business Research 67(1): 2891-2902. http://dx.doi.org/10.1016/j.jbusres.2012.06.004

Capaldo, G.; Iandoli, L.; Raffa, M.; Zollo, G. 2003. The evaluation of innovation capabilities in small software firms: a methodological approach, Small Business Economics 21: 343-354.

http://dx.doi.org/10.1023/A:1026158904245 
Cheng, Y. L.; Lin, Y. H. 2012. Performance evaluation of technological innovation capabilities in uncertainty, Procedia - Social and Behavioural Sciences 40: 287-314.

http://dx.doi.org/10.1016/j.sbspro.2012.03.193

Chen, I. S. 2016. A combined MCDM model based on DEMATEL and ANP for the selection of airline service quality improvement criteria: a study based on the Taiwanese airline industry, Journal of Air Transport Management 57: 7-18. http://dx.doi.org/10.1016/j.jairtraman.2016.07.004

Christensen, J. F. 1995. Asset profiles for technological innovation, Research Policy 24: 727-745. http://dx.doi.org/10.1016/0048-7333(94)00794-8

Coombs, J. E.; Bierly, P. E. 2006. Measuring technological capability and performance, $R \& D$ Management 36(4): 421-438. http://dx.doi.org/10.1111/j.1467-9310.2006.00444.x

EARTO. 2010. Impacts of European RTOs: a study of social and economic impacts of research and technology organizations [online], [cited 30 November 2011]. Technopolis Group. Available from Internet: www.technopolis-group.com

Ferreira, F. A. F.; Santos, S. P.; Dias, V. M. C. 2014. An AHP-based approach to credit risk evaluation of mortgage loans, International Journal of Strategic Property Management 18(1): 38-55. http://dx.doi.org/10.3846/1648715X.2013.863812

Fontela, E.; Gabus, A. 1976a. The DEMATEL Observer, DEMATEL 1976 Report. Battelle Geneva Research Center, Geneva, Switzerland.

Fontela, E.; Gabus, A. 1976b. Current perceptions of the world problematique, in C. W. Churchman, R. O. Mason (Eds.). World modelling: a dialogue. Amsterdam/Oxford: North-Holland Publishing Company, 81-88.

Gabus, A.; Fontela, E. 1972. World problems, an invitation to further thought within the framework of DEMATEL. Battelle Geneva Research Center, Geneva, Switzerland.

Galbraith, J. R. 1996. Designing the innovating organization, in K. Starkey (Ed.). How organizations learn. London: International Thomson Business Press.

Garcia, R.; Calantone, R. 2002. A critical look at technological innovation typology and innovativeness terminology: a literature review, Journal of Product Innovation Management 19: 110-132. http://dx.doi.org/10.1016/S0737-6782(01)00132-1

García-Muiña, F. E.; Navas-López, J. E. 2007. Explaining and measuring success in new business: the effect of technological capabilities on firm results, Technovation 27(1-2): 30-46.

http://dx.doi.org/10.1016/j.technovation.2006.04.004

Gibbons, M.; Limoges, C.; Nowotny, H.; Schwartzman, S.; Scott, P.; Trow, M. 1994. The new production of knowledge: the dynamics of science and research in contemporary societies. London: SAGE.

Guan, J. C.; Yam, R. C. M.; Mok, C. K.; Ma, N. 2006. A study of the relationship between competitiveness and technological innovation capability based on DEA models, European Journal of Operational Research 170: 971-986. http://dx.doi.org/10.1016/j.ejor.2004.07.054

Gupta, H.; Barua, M. K. 2016. Identifying enablers of technological innovation for Indian MSMEs using best-worst multi criteria decision making method, Technological Forecasting and Social Change 107: 69-79. http://dx.doi.org/10.1016/j.techfore.2016.03.028

Hagedoorn, J. 2002. Inter-firm partnerships: an overview of major trends and patterns since 1960, Research Policy 31: 477-492. http://dx.doi.org/10.1016/S0048-7333(01)00120-2

Heng, T. 2011. The empirical analysis of enterprise scientific and technological innovation capability, Energy Procedia 5: 258-1263. http://dx.doi.org/10.1016/j.egypro.2011.03.219

Horng, J. S.; Liu, C. H.; Chou, S. F.; Yin, Y. S.; Tsai, C. Y. 2014. Developing a novel hybrid model for industrial environment analysis: a study of the gourmet and tourism industry in Taiwan, Asia Pacific Journal of Tourism Research 19(9): 1044-1069.

http://dx.doi.org/10.1080/10941665.2013.837399 
Hu, M.-C. 2012. Technological innovation capabilities in the thin film transistor-liquid crystal display industries of Japan, Korea, and Taiwan, Research Policy 41(3): 541-555.

http://dx.doi.org/10.1016/j.respol.2011.10.013

Lall, S. 1992. Technological capabilities and industrialization, World Development 20(2): 165186. http://dx.doi.org/10.1016/0305-750X(92)90097-F

Lin, Y.-Y.; Pan, N.-H. 2014. Multi period performance assessment model for the site property management, International Journal of Strategic Property Management 18(4): 332-343. http://dx.doi.org/10.3846/1648715X.2014.970596

OECD. 1991. The nature of innovation and the evolution of the productive system. Technology and productivity-the challenge for economic policy. Paris: OECD.

OECD/Eurostat. 2005. Oslo Manual: Guidelines for collecting and interpreting innovation data. $3^{\text {rd }}$ Edition. The measurement of scientific and technological activities. Paris: OECD Publishing. http://dx.doi.org/10.1787/9789264013100-en

Opricovic, S.; Tzeng, G. H. 2003. Defuzzification within a multi criteria decision model, International Journal of Uncertainty, Fuzziness and Knowledge-Based Systems 11(5): 635-652. http://dx.doi.org/10.1142/S0218488503002387

Panda, H.; Ramanathan, K. 1996. Technological capability assessment of a firm in the electricity sector, Technovation 16(10): 561-588. http://dx.doi.org/10.1016/S0166-4972(97)82896-9

Pak, K. B. 2011. Multi-criteria decision making for sustainable energy planning in Turkey: Thesis for the degree of doctor of philosophy in engineering management. Marmara University, The Institute for Graduate Studies in Pure and Applied Sciences.

Peng, K.-H.; Tzeng, G.-H. 2013. A hybrid dynamic MADM model for problem-improvement in economics and business, Technological and Economic Development of Economy 19(4): 638-660. http://dx.doi.org/10.3846/20294913.2013.837114

Pourahmad, A.; Hosseini, A.; Banaitis, A.; Nasiri, H.; Banaitienė, N.; Tzeng, G. H. 2015. Combination of fuzzy-AHP and DEMATEL-ANP with GIS in a new hybrid MCDM model used for the selection of the best space for leisure in a blighted urban site, Technological and Economic Development of Economy 21(5): 773-796. http://dx.doi.org/10.3846/20294913.2015.1056279

Saaty, T. L. 1996. Decision making with dependence and feedback: the analytic network process. Pittsburgh: RWS Publications.

Shafia, M. A.; Shavvalpour, S.; Hosseini, M.; Hosseini, R. 2016. Mediating effect of technological innovation capabilities between dynamic capabilities and competitiveness of research and technology organizations, Technology Analysis \& Strategic Management 28(7): 811-826.

http://dx.doi.org/10.1080/09537325.2016.1158404

Teece, D. J.; Pisano, G.; Shuen, A. 1997. Dynamic capabilities and strategic management, Strategic Management Journal 18(7): 509-533.

http://dx.doi.org/10.1002/(SICI)1097-0266(199708)18:7<509::AID-SMJ882>3.0.CO;2-Z

Urueña, A.; Hidalgo, A.; Arenas, A. E. 2016. Identifying capabilities in innovation projects: evidences from eHealth, Journal of Business Research. (Article in Press)

http://dx.doi.org/10.1016/j.jbusres.2016.04.041

Volkan, M. 2012. A model proposal oriented to measure technological innovation capabilities of business firms: a research on automotive industry, Procedia - Social and Behavioural Sciences 41: 147-159. http://dx.doi.org/10.1016/j.sbspro.2012.04.019

Wang, C. H.; Lub, I. Y.; Chen, C. B. 2008. Evaluating firm technological innovation capability under uncertainty, Technovation 28: 349-363. http://dx.doi.org/10.1016/j.technovation.2007.10.007 Wonglimpiyarat, J. 2010. Innovation criteria and the innovative capacity of nations, Futures 42(3): 247-253. http://dx.doi.org/10.1016/j.futures.2009.11.010 
Yam, R. C. M.; Guan, J. C.; Pun, K. F.; Tang, E. P. Y. 2004. An audit of technological innovation capabilities in Chinese firms: some empirical findings in Beijing, China, Research Policy 33(8): 1123-1140. http://dx.doi.org/10.1016/j.respol.2004.05.004

Yang, C.; Zhang, Q.; Ding, S. 2015. An evaluation method for innovation capability based on uncertain linguistic variables, Applied Mathematics and Computation 256: 160-174.

http://dx.doi.org/10.1016/j.amc.2014.12.154

Zadeh, L. A. 1965. Fuzzy sets, Information and Control 8(3): 338-353.

http://dx.doi.org/10.1016/S0019-9958(65)90241-X

Zhao, S. L.; Song, W.; Zhu, D. Y.; Peng, X. B.; Cai, W. 2013. Evaluating China's regional collaboration innovation capability from the innovation actors perspective - an AHP and cluster analytical approach, Technology in Society 35(3): 182-190.

http://dx.doi.org/10.1016/j.techsoc.2013.06.001

Sara Sadat MORTAZAVI RAVARI is Ph.D. Student in Management of Technology at University of Tehran, Iran. She holds her Master degree in Management of Technology at University of Alame Tabatabaie, Iran. Her research interests focus on technological strategy planning and decision support systems.

Ehsan MEHRABANFAR is MA in Organisational Change \& Development Studies at Global Development Institute, The University of Manchester, Manchester, UK. BSc in petroleum engineering from Petroleum University of Technology (2010), \& MBA from Department of Management, Science \& Technology, Amir Kabir University of Technology, Tehran, Iran. Authors of over 20 papers published in national and international journals. Research interests include developmental economics, change, development studies, strategic planning, organisational development.

Audrius BANAITIS is a Professor in the Department of Construction Economics and Property Management at Vilnius Gediminas Technical University, Lithuania. His research interests include project/ risk management and project success, property management, sustainability and construction industry development, innovation management, strategic management, multiple criteria decision making: applications in construction and real estate.

Nerija BANAITIENE is an Associated Professor in the Department of Construction Economics and Property Management at Vilnius Gediminas Technical University, Lithuania. Her research interests include project/risk management and project success, property management, multiple criteria decision making: applications in construction and real estate. 